\title{
Three-dimensional Characteristics of the Interface Epithelium- Connective Tissue Surface of Finger's Lamina Propria of Cebus apella Monkey: Scanning Electron Microscopy Study
}

\author{
Características Tri-dimensionales Superficiales de la Interfase del Tejido Epitelial-Conectivo de la \\ Lámina Propia de los Dedos de Monos Cebus apella: Estudio con Microscopía Electrónica de Barrido
}

\author{
${ }^{*, * *}$ Ii-sei Watanabe; "Juliana Plácido Guimarães; ${ }^{* * * *}$ Mamie Misuzaki Iyomasa; *Maria Angélica Miglino; ${ }^{* * * * *}$ Marília Gabriela de \\ Oliveira Lopes; Márcia Consentino ${ }^{* * * * * *}$ Kronka Sosthines \& ${ }^{* * * * *}$ Marcelo Cavenaghi Pereira da Silva
}

WATANABE, I.; GUIMARÃES, J. P.; IYOMASA, M. M.; MIGLINO, M. A.; LOPES, M. G. O.; SOSTHINES, K. \& DA SILVA, M. C. P. Three-dimensional characteristics of the interface epithelium-connective tissue surface of finger's lamina propria of Cebus apella monkey: scanning electron microscopy study. Int. J. Morphol., 26(2):325-330, 2008.

SUMMARY: In the present paper were analysed the three-dimensional characteristics of the interface epithelium-connective tissue surface of finger prints of Cebus apella monkey employing the scanning electron microscopic methods. The connective tissue core (CTC) and epithelial papillae were examined verifying the three-dimensional configuration of the tissue projections. The samples were fixed in Bouin solsution for histologic preparations and in modified Karnovsky for examine to observe in scanning electron microscopy. After treatment in the $10 \% \mathrm{NaOH}$ solution during 3 to 5 days, the surface of finger prints revealed a distribution of CTC of lamina propria in situ showing original three-dimensional SEM images. The linear and circular dispositions CTC, and the furrows were clearly identified. Each pointed papilla presented a large base and longitudinal disposition of thick collagen fiber bundles and in some areas with a complex reticular formations. The longitudinal furrows between the pointed papillae exhibited a dense layer of connective tissue and showed only low CTC or laminar in shape. The presence of numerous foramina of sweat gland were noted in three-dimensional SEM images.

KEY WORDS: Skin; Finger; Collagen fibers; Cebus apella; Scanning electron microscopy.

\section{INTRODUCTION}

The histological and ultrastructural observations of connective tissue core (CTC) of lamina propria of mucosae have been reported by several authors. The CTC structure of human tongue was studied by Horstmann (1954) using light microscopy. Kobayashi et al. (1987) reported the threedimensional aspects of the CTC of the neonatal dogs, after treatment in $\mathrm{HCl}$ solution in order to explore the CTC, concluding that the CTC of filiform papillae present a elliptical protrusion and in the fungiform papilla a round in shape. Also, Kobayashi (1990) revealed that the lingual mucosa of guinea pig present numerous projections of CTC formed by three or more stick's protrusions in shape. The large and small conical papillae and ducts of salivary gland were noted in the posterior region of tongue. The three-dimensional architecture of CTC in lamina propria of rat soft palate were demonstrated by Nakano (1992). Kobayashi (1992) reported the architecture of CTC lingual papillae of Tupais glis observing that the CTC of filliform papillae showed a human hand and of the fungiform in colunar form. Iwasaki et al. (1992) demonstrated the structures of interface epithelium-connective tissue of turtle's tongue (Clemmys japonica). Watanabe et al. (1992) showed the structures of lingual mucosa Dasypus novemcinctus mentioning that the CTC presented in form finger tips. Misumi \& Akiyoshi (1984) evidenciated the CTC of human finger prints detecting the papillae in rows and of different sizes.

\footnotetext{
Department of Surgery, Domestic Animal Anatomy Section, Faculty of Veterinary Medicine, University of Sao Paulo

** Department of Anatomy, Institute of Biomedical Sciences, University of Sao Paulo.

*** Department of Morphology, Phisiology and Estomatology, Faculty of Dentistry, campus of Ribeirão Prêto, University of Sao Paulo

***** Faculty of Sciences and Health, University of Vale do Paraiba, São José dos Campos, São Paulo.

******* Department of Morphology, Biological Sciences Center, Federal Universty of Belém, campus of Guama, Belém, PA, Brazil

*******Departmenmt of Morphology, Federal University of Sao Paulo, UNIFESP, Sao Paulo.
} 
WATANABE, I.; GUIMARÃES, J. P.; IYOMASA, M. M.; MIGLINO, M. A.; LOPES, M. G. O.; SOSTHINES, K. \& DA SILVA, M. C. P. Three-dimensional characteristics of the interface epithelium-connective tissue surface of finger's lamina propria of Cebus apella monkey: scanning electron microscopy study. Int. J. Morphol., 26(2):325-330, 2008.

The aim of present paper is to demonstrate the characteristics of interface epithelium-connective tissue of finger prints of monkey Cebus apella, using scanning electron microscopic method.

\section{MATERIAL AND METHOD}

In then present study were used the palmar skin of five monkeys Cebus apella. The animals were anesthetized by intraperitoneal injection of pentobarbital sodic and perfused with the modified Karnovsky solution containing $2.5 \%$ of glutaraldehyde, $2 \%$ paraformaldehyde in sodium phosphate buffer at $0.1 \mathrm{M}(\mathrm{pH}$ 7.4). For light microscopy sections, the specimens were fixed in Bouin solution during $8 \mathrm{hs}$ and embedded in Paraplast resin. Thick sections of 6 micrometers were mounted and stained by Hematoxilyneosin, Azo-Carmin and Picrosirius. For scanning electron microscopy, after fixation by perfusion, the samples were dissected and fixed in same solution during $12 \mathrm{~h}$ at $4^{\circ} \mathrm{C}$. The samples were treated in $10 \%$ sodium hydroxide solution for 3 to 5 days, at room temperature, according to the technique reported by Ohtani (1987). Then, the samples were rinsed in distilled water for several days and posfixed in $1 \%$ aqueous osmiun tetroxide solution during $2 \mathrm{hs}$ at $4^{\circ} \mathrm{C}$. The samples were immersed in $1 \%$ aqueous solution of tannic acid during 90 minutes at room temperatura (Murakami, 1974).

Then, the samples were dehydrated in increasing series of ethanol, dehydrated by crítical point dryer utilizing Balzers, CPD-030 device with liquid carbon dioxide and coated with gold in "Íons Sputter" Balzers SCD-040 apparatus. The observations were made in a scanning electron microscopy Jeol, JSM-840.

\section{RESULTS}

Light microscopy observations revealed that the epithelial layer measures $171.58 \mu \mathrm{m} \pm 37.01 \mu \mathrm{m}$, containing a dense connective tissue with dermal and epidermal portions. The thick connective tissue layer containing the CTC are evidentiated in stained sections of Hematoxilyn-eosin and Azo-Carmin (Figs.1A and 1B). The sections stained with Picrosirius and examined by polarized light microscopy may detecte the presence of thick collagen fibers of type I and III (Fig. 2).

The scanning electron microscopic observations in the samples treated with sodiun hydroxide solution revealed that the surface of interface epithelium-connective tissue of finger prints were constituted by CTC having the bundles of collagen fibers in situ (Fig. 3). The CTC formations were encountered in all extensions of lamina própria revealing the circular and longitudinal dispositions in three-dimensional SEM images (Fig.4). Bifurcated and trifurcated papillae were noted in some areas. At base of papilla showed usually thick connective tissue. In the surface of furrow of each papilla, the connective tissue projections were generally small and few. The connective tissue projections present a pointed in shape revealing clearly a disposition of collagen fiber bundles (Fig. 5). The elongated and conical CTC possessed at their base numerous collagen fiber bundles in linear and irregular disposition (Fig. 6). Each papilla present a longitudinal disposition of collagen fiber bundles (Fig. 7). The pointed CTC delimited a longitudinal furrows (Fig.8). The surface of furrow present a flat área and contain several foramina of ducts. At high magnification of figures, may observe a distribution of the bundles of longitudinal fibers (Fig. 9). Also, the circular disposition of collagen fibers and
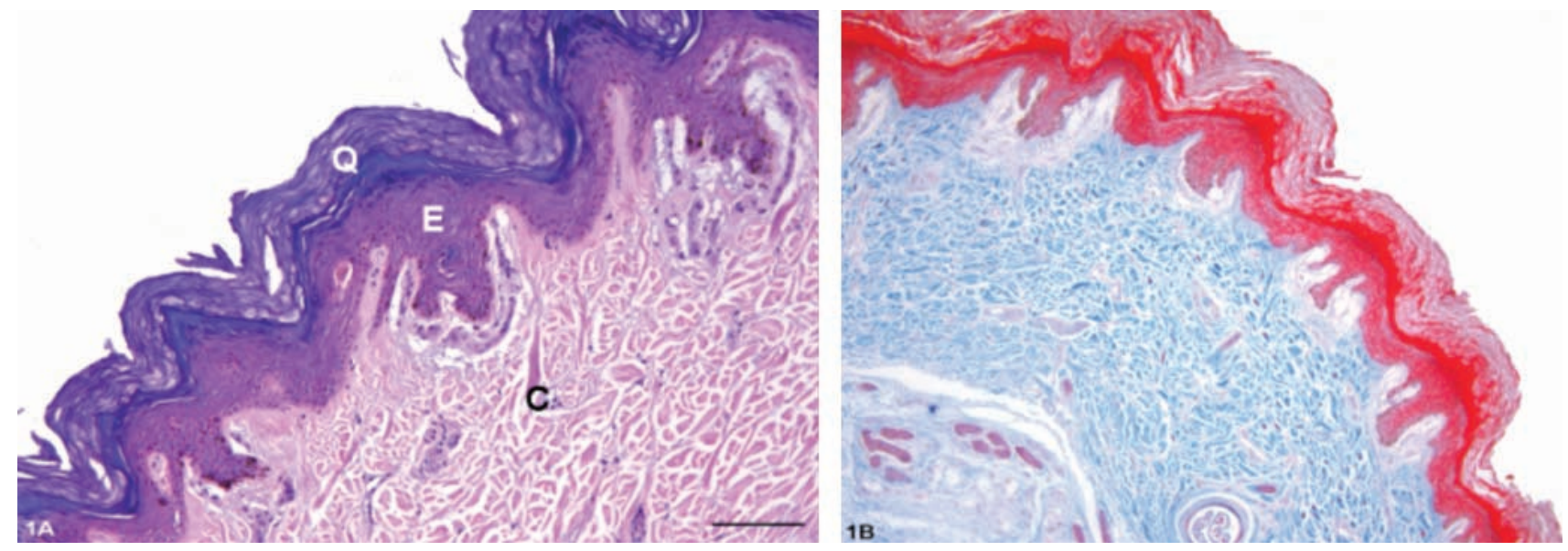

Fig.1. Photomicrography of finger print skin of Cebus paella monkey. A: General aspect, showing the epithelium (E), queratinized layer

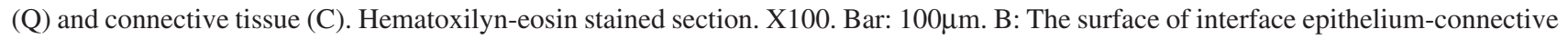
tissue, with CTC projections may be seen. Azo-Carmin stained section. X100. Bar: $100 \mu \mathrm{m}$. 
WATANABE, I.; GUIMARÃES, J. P.; IYOMASA, M. M.; MIGLINO, M. A.; LOPES, M. G. O.; SOSTHINES, K. \& DA SILVA, M. C. P. Three-dimensional characteristics of the interface epithelium-connective tissue surface of finger's lamina propria of Cebus apella monkey: scanning electron microscopy study. Int. J. Morphol., 26(2):325-330, 2008.
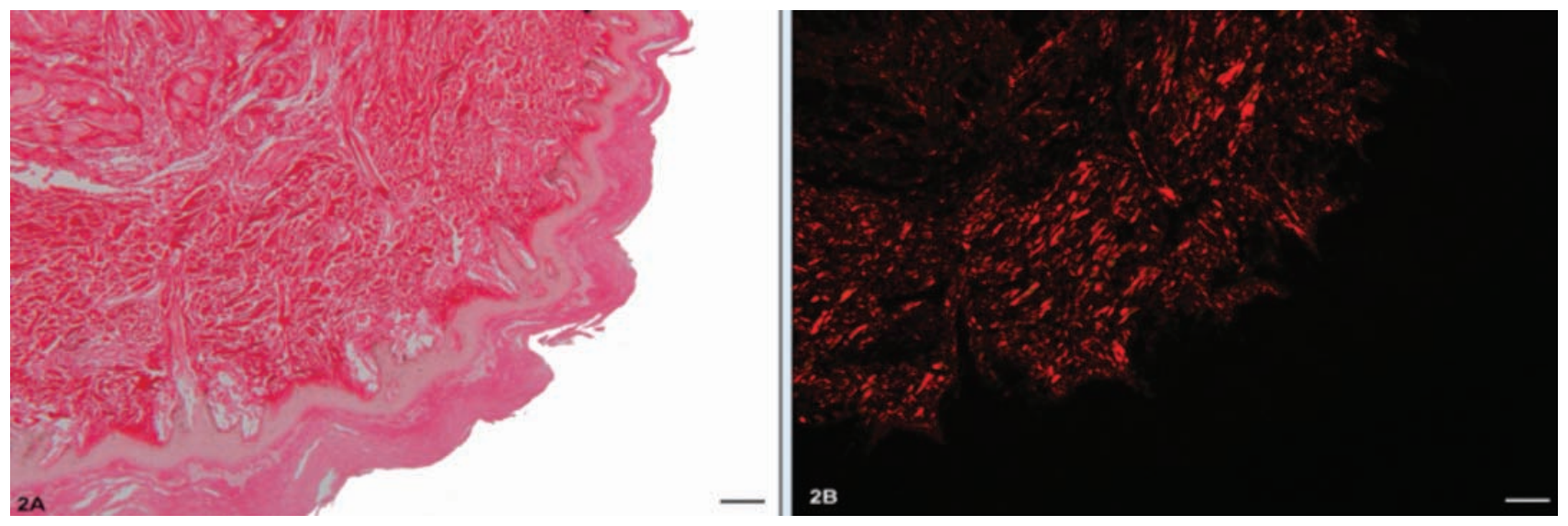

Fig. 2 A: Photomicrography of Picrosirius stained section showing a distribution of connective tissue in red. X100. Bar: 100 $\mu$ m. B:

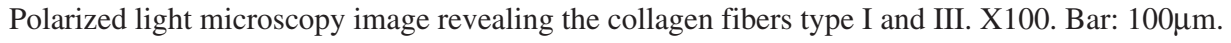
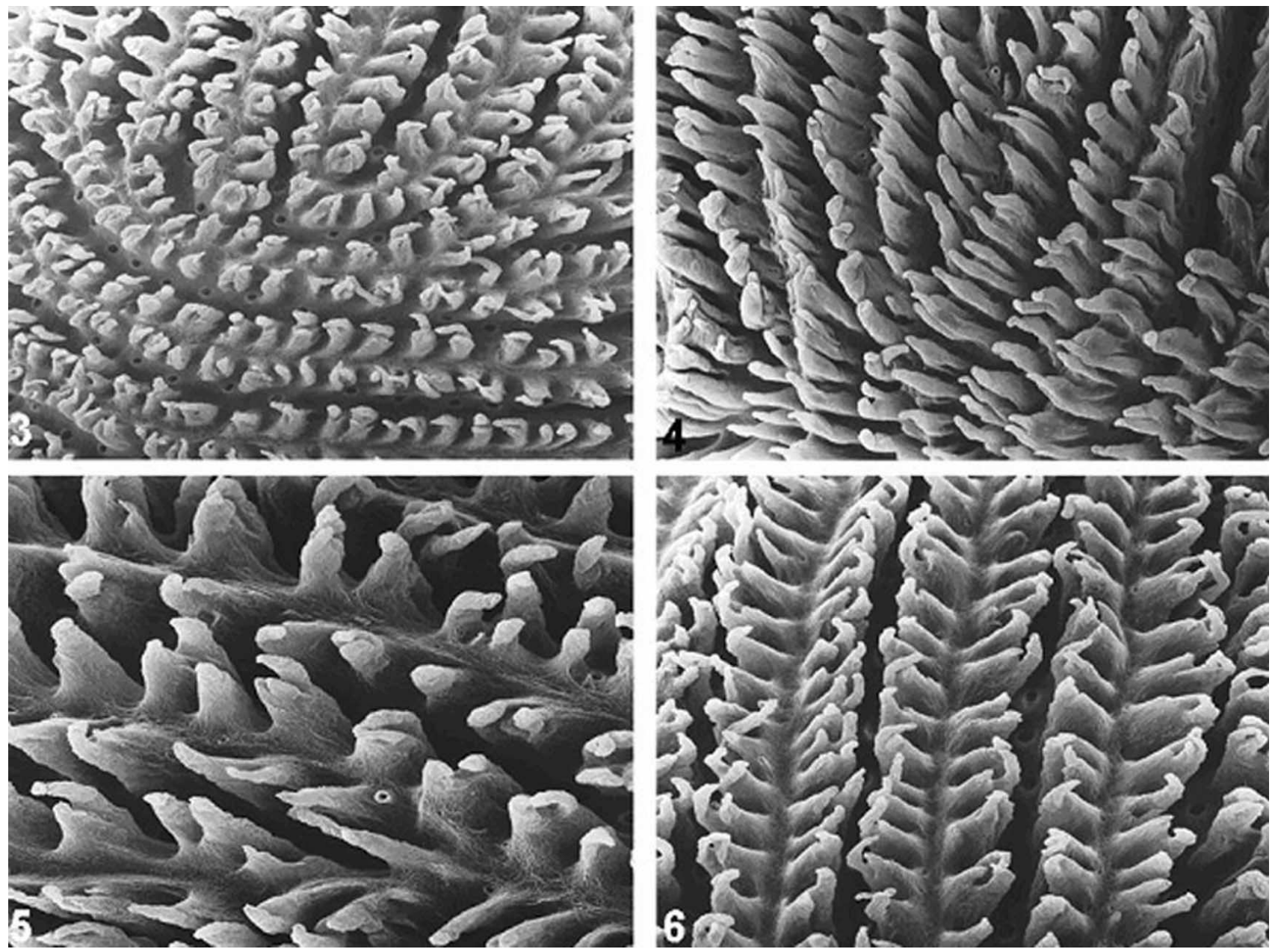

Fig. 3. Sample treated with $\mathrm{NaOH}$ solution. Surface of interface epithelium-connective tissue of circular disposition. 50X.

Fig. 4. Shows the elongate CTC longitudinally disposed having some bifurcate or trifurcated tips. 50X.

Fig. 5. The space between CTC projections revealing the dense collagen fibers surface. 100X.

Fig. 6. Sample treated with $\mathrm{NaOH}$ solution. The interface epithelium-connective surface revealed the space between the CTC containing a dense collagen bundles. 70X. 
WATANABE, I.; GUIMARÃES, J. P.; IYOMASA, M. M.; MIGLINO, M. A.; LOPES, M. G. O.; SOSTHINES, K. \& DA SILVA, M. C. P. Three-dimensional characteristics of the interface epithelium-connective tissue surface of finger's lamina propria of Cebus apella monkey: scanning electron microscopy study. Int. J. Morphol., 26(2):325-330, 2008.
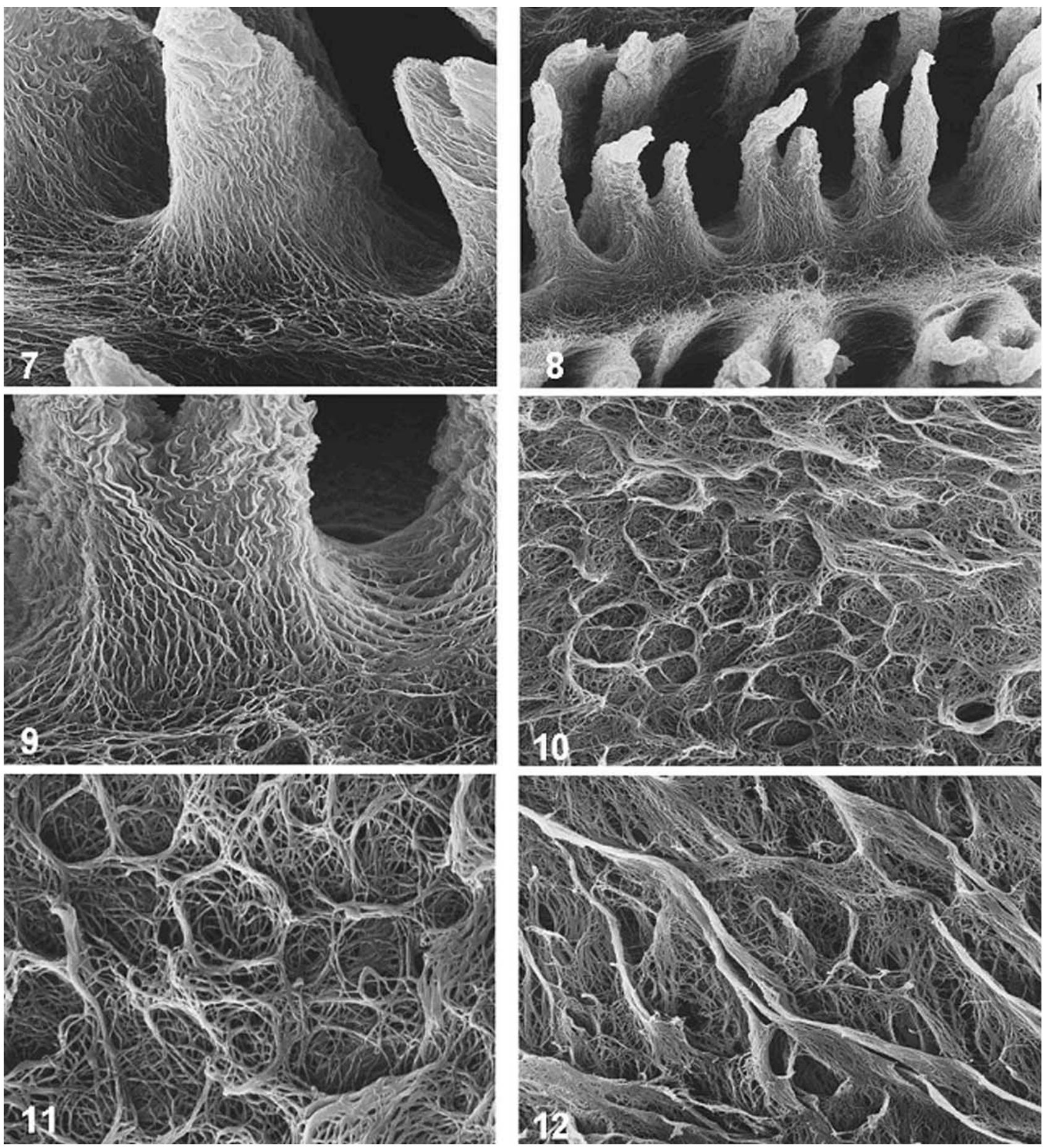

Fig. 7. Samples treated with $\mathrm{NaOH}$ solution. The interface epithelium-connective tissue revealed CTC and the adjacent spaces. A longitudinal disposition of collagen fibers is clearly seen. 500X.

Fig. 8. The surface of interface epithelium-connective tissue and the spaces are shown. The details of the base are clearly noted. 200X. Fig. 9. At high magnification, a vertical disposition of collagen fibers are identified. 700X.

Fig. 10. The reticular fibers are clearly shown. 5.000X.

Fig. 11. At high magnification the circular formations are seen. 10.000X.

Fig. 12. The longitudinal disposition of collagen fiber bundles are noted. 5.000X. 

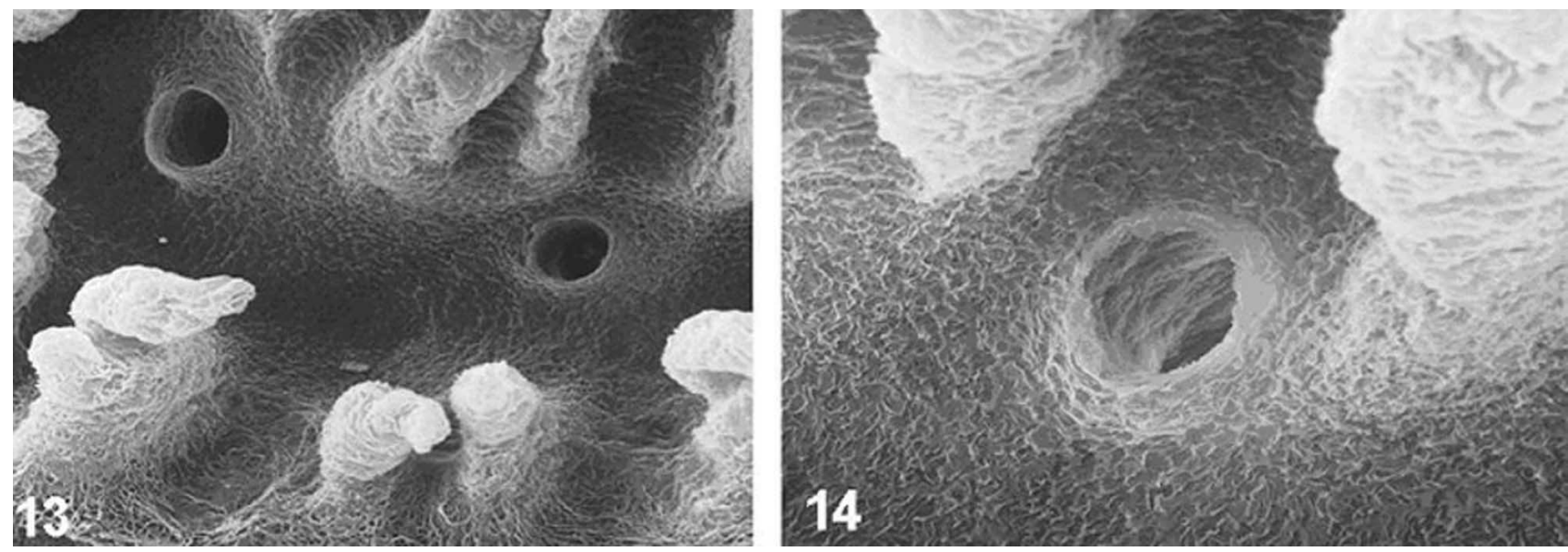

Fig. 13. The presence of foramina of sweat gland duct are shown. 300X. Fig. 14. At high magnification may observe a disposition of collagen fiber bundles surrounding the forame of sweat gland duct. $700 \mathrm{X}$.

the spaces which permit the passage of small capillaries and bundles of nerve fibers can be see (Fig. 10). The circular aspect of the collagen fibers revealed a network on the surface and the trabeculations (Fig.11). The figure 12 shows at high magnification a longitudinal distribution of collagen fibers in each CTC. The duct of sweat gland were observed on the surface between the longitudinal disposed papillae (Fig.13). The duct of sweat gland was surrounded by circular bundles of collagen fibers noted in three-dimensional SEM images (Fig.14)

\section{DISCUSSION}

Our results revealed clearly the presence of CTC of lamina própria identifying the surface of interface epitheliumconnective tissue, after treatment with $\mathrm{NaOH}$ solution. Then samples analysed by scanning electron microscope demonstrated the morphology of the papillae, which are usually pointed in shape. Our data showed that the exposition of structures of lamina própria evidenciated CTC in original localization and in three-dimensional SEM images. These similar characteristics of CTC in other animals have been reported by Kobayashi (1990, 1992), Kobayashi et al., Ohtani et al. (1988) and Watanabe et al. (1992, 1994). Considering the functional aspect, it may confirm that the structures of CTC located between epithelial layer and connective tissue may act to increase the contact surface in both sides and promote the junction and facilitate the blood suppliment (Kobayashi et al.; Kobayashi, 1990, 1992; Nakano).

Although, our results examining the finger prints of monkeys can be noted that the characteristics of CTC, and the details of disposition of collagen fiber bundles in the lamina propria revealing in three-dimensional SEM images. Other aspects that our results may identify the surface of interface epithelium-connective tissue where diferents regions of fingers of Cebus apella monkey revealed a disposition of the collagen fibers in each papilla. Nakano suggested that the architecture of interface epithelium- connective tissue must to be determine genetically. Recently, several researchers demonstrated that CTC of tongue mucosa in various species of animals using SEM (Kobayashi et al.; Nagato et al., 1989; Kobayashi, 1990; Watanabe et al., 1992; Silva et al., 2002). According to the authors, the architecture of CTC is variable due to the type of lingual papillae. Although, it was related that the filiform papillae of tongue presented morphological variations not only between the species, but also between different localizations on the tongue surface. The CTC in the present study represent the general external conformation of fingers and of each type of papilla having a framework formed by bundles of collagen fibers disposed in different directions. Our results obtained in the fingers of monkeys presented CTC relatively uniform in size following the external conformation and size and shape of papillae presenting small variations comparing to those observed in the oral mucosa of mammals.

\section{ACKNOWLEDEGMENTS}

The authors express many thanks to Mr. Sebastião Aparecido Bioleta, Mrs. Sonia Regina Yokomizo de Almeida and Mrs. Marta Maria da Silva Righetti for their technical assistance. 
WATANABE, I.; GUIMARÃES, J. P.; IYOMASA, M. M.; MIGLINO, M. A.; LOPES, M. G. O.; SOSTHINES, K. \& DA SILVA, M. C. P. Three-dimensional characteristics of the interface epithelium-connective tissue surface of finger's lamina propria of Cebus apella monkey: scanning electron microscopy study. Int. J. Morphol., 26(2):325-330, 2008.

WATANABE, I.; GUIMARÃES, J. P.; IYOMASA, M. M.; MIGLINO, M. A.; LOPES, M. G. O.; SOSTHINES, K. \& DA SILVA, M. C. P. Características tri-dimensionales superficiales de la interfase del tejido epitelial-conectivo de la lámina propia de los dedos de monos Cebus apella: Estudio con microscopía electrónica de barrido. Int. J. Morphol., 26(2):325-330, 2008.

RESUMEN: Se analizaron tridimensionalmente las características de la interfase del tejido epitelio-conectivo en la superficie de huellas dactilares de mono Cebus apella, empleando el microscopio electrónico de barrido. El núcleo del tejido conectivo (NTC) y las papilas epiteliales se examinaron en las tres dimensiones. Las muestras fueron fijadas en solución histológica Bouin para los preparativos y en Karnovsky modificada para examinar y observar en el microscopio electrónico de barrido. Después del tratamiento en solución de $\mathrm{NaOH}$ al 10\%, durante 3 a 5 días, la superficie de las huellas dactilares revelaron una distribución de NTC de lámina propia in situ mostrando imágenes en tres dimensiones originales con microscopio electrónico de barrido. Las disposiciones lineal y circular del NTC están claramente identificadas. Cada papila señalada presenta una gran base y la disposición longitudinal de gruesos haces de fibras de colágeno y, en algunas zonas con formaciones de un complejo reticular. Los surcos longitudinales entre las papilas señaladas mostraron una densa capa de tejido conectivo con NTC bajos o de forma laminar. La presencia de numerosos forámenes de las glándulas sudoríparas se observaron en tres dimensiones.

PALABRAS CLAVE: Piel; Dedo; Fibras de colágeno; Cebus apella; Microscopía electrónica de barrido.

\section{REFERENCES}

Horstmann, E. Morphology and morphogenesis of the papillary body of the oral mucosa in man. Z. Zellforsch. Mikrosk. Anat., 39(5):479-514, 1954.

Iwasaki, S.; Asami, T.; Asami, Y. \& Kobayashi, K. Fine structure of the dorsal epithelium of the tongue of the Japanese terrapin, Clemmys japonica (Cheloia, Emydinae). Arch. Histol. Cytol., 55(3):295-305, 1992.

Kobayashi, K. Three-dimensional architecture of the connective tissue core of the lingual papillae in the guinea pig. Anat. Embryol. (Berl), 182(3):205-13, 1990

Kobayashi, K. Stereo architeture of the interface of the epithelial cell layer and connective tissue core of the foliate papilla in the rabbit tongue. Acta Anat. (Basel), 143(2):109-17, 1992.

Kobayashi, K.; Miyata, K. \& Iino, T. Three-dimensional structures of the connective tissue papillae of the tongue of Newborn dogs. Arch. Histol. Jap., 50(3):347-57, 1987.

Misumi, Y. \& Akiyoshi, T. Scanning electron microscopic structure of the finger print as related to the dermal surface. Anat. Rec., 208(1):49-55, 1984.

Murakami, T. A revised tannin-osmium method for non-coated scanning electron microscope specimens. Arch. Histol. Jpn., 36(3):189-93, 1974.

Nagato, T.; Nagaki, M.; Murakami, T. \& Tanioka, H. Three dimensional architeture of rat lingual filiform papillae with special reference to the epithelium- connective interface. J. Anat., 165:177-89, 1989.

Nakano, T. NaOH cell maceration scanning electron microscopic studies on the architeture of the lamina propria of the mouse palate. Auris Nasus Larynx, 19(2):133-42, 1992.
Ohtani, O. Three-dimensional organization of the connective tissue fibers of the human pancreas: a scanning electron microscopic study of $\mathrm{NaOH}$ treated-tissues. Arch. Histol. Jpn., 50(5):55766, 1987.

Ohtani, O.; Ushiki, T.; Taguchi, T. \& Kikuta, A. Collagen fibrillar networks as skeletal frameworks: a demonstration by cellmaceration/scanning electron microscope method. Arch. Histol. Cytol., 51(3):249-61, 1988.

Silva, M. C. P.; Watanabe, I. \& Kronka, M. C. Three-dimensional architecture of the connective tissue core and surface structures of the lingual papillae in the rabbit. Histol. Histopathol., 17(2):455-61, 2002.

Watanabe, I.; Morais, J.O.R.; Iyomasa, M.M. \& Konig Jr., B. Stereo architecture of the connective tissue cores of the gingiva in the Cebus apella monkey. Rev. Bras. Ciênc. Morfol., 116:45-50, 1994.

Watanabe, I.; Morais, J.Q.R.; Yokoyama, R.; Inokuchi,T. \& Hamasaki, M. Three- dimensional structures of the subepithelial connective tissue papillae of the armadillo, Dasypus novencinctus tongue. Rev. Chil.Anat.,10:97-103, 1992.

Correspondence to:

Prof. Dr. li-sei Watanabe, Professor Titular

Departamento de Anatomia Humana

Instituto de Ciências Biomédicas

Universidade de São Paulo

Avenida Lineu Prestes, 2415

CEP 05508-900

Cidade Universitária

Received: 03-12-2007

São Paulo, BRASIL

Accepted: 22-02-2008

E mail: watanabe@icb.usp.br; watanabe@usp.br 